\title{
CONTRIBUTIONS TO THE HISTORY OF ARCHAEOLOGICAL INVESTIGATION IN THE SVRLJIG AREA
}

\author{
UDC 904(497.11)
}

\section{Irena Ljubomirović}

University of Niš, Faculty of Philosophy, Department of History, Serbia

\begin{abstract}
Archaeological sites on the territory of south-eastern Serbia were visited for the first time by the famous writer Feliks Kanic (1824-1904) in the second half of the nineteenth century. He started work on making the archaeological map of Serbia in 1861 and that task would later be continued by Nikola Vulic (1872-1945). He visited archaeological sites on the territory of Niš as well as Svrljig and its surroundings. Vulic wrote facts about these archaeological sites in his unpublished writings titled "Appendixes for the archaeological map section of Niš" - a part of the scientist's unpublished manuscripts which are kept at the National Library of Serbia. In this work we will expose facts from Vulic's unpublished manuscripts.
\end{abstract}

Key words: Feliks Kaniz, archaeological map, Svrljig.

\section{INTRODUCTION}

Archaeological sites on the territory of South-East Serbia were first visited by the famous travel writer Felix Kanitz (1824-1904) in the second half of the nineteenth century. He began work on the archaeological map of Serbia in 1861 only for the work to be continued by Nikola Vulić (1872-1945) by the early twentieth century. In addition to locations in the city of Niš, he visited Svrljig and its surroundings as well. Information on the archaeological findings from these localities are in Vulić's unpublished notes titled "Appendices to the archaeological map section of Niš", which are part of Vulić's written legacy that is kept in the National Library of Serbia. In this paper, we will present data from Vulić's unpublished writings, too.

Felix Kanitz (1824-1904), the famous travel writer of Jewish origin, was born in the Hungarian town of Obuda, where he completed his primary education. He continued his education in Budapest as well, and in 1847 he moved to Vienna, where he attended the

Received March 31, 2018 / Accepted October 14, 2018

Corresponding author: Irena Ljubomirović

University of Niš, Faculty of Philosophy, Cirila i Metodija 2, 18000 Niš, Serbia

E-mail: irena.ljubomirovic@filfak.ni.ac.rs 
Academy of Fine Arts. His Art education was supplemented in Munich, Dresden and Nuremberg (Timotijević 2011, 93-115). In 1856 Kanitz returned and permanently settled in Vienna, where he made friends with the archaeologist Francesco Carrara who improved Kanitz's knowledge of the discipline. Kanitz started showing increasing interest in the Balkans after a disturbance of the Christian population in the western part of the Balkans in 1858. At the request of Johann Jakob Weber, editor of the prestigious German newspaper "Illustrierte Zeitung", to which Kanitz contributed, he visited the territory of Bosnia, Herzegovina, Montenegro and Dalmatia, and published his results in 1858 and in 1859 during that trip (Timotijević 2011, 117). This trip was a decisive factor for Kanitz's further interest and he ceased to be a mere newspaper illustrator, but also devoted himself to the research on the then relatively unknown Balkan region. During a tour of the Balkans, Kanitz visited the territory of the Principality (from 1882 the Kingdom) of Serbia on several occasions. He first visited Serbia in 1859 and stayed there in 1860 and in 1861, and on that occasion made series of sketches, drawings and watercolors of different content. Kanitz wrote a brief description of the ancient monuments on the territory of the Principality of Serbia, and published them in the extensive scientific study illustrated Die römischen Funde in Serbien (Kanitz 1861, 195-2013). The text and illustrations are divided in the study, but on the basis of their selection, the complexity of Kanitz's access to the visual presentation of the ancient monument is apparent.

Kanitz first visited the Southeast parts of the Principality of Serbia, including the city of Niš in 1859, but apart from a few Roman monuments outside the Hunkjar-mosque there were not any ancient remains elsewhere. Since the antiquity in Niš had previously been described, the only explanation for the disappearance of the remains of the ancient city was that they were built into the fortress and other buildings of solid material which were being erected by the Turks within a period of two centuries. During his second visit to Niš in 1864 he began his research of the Fortress, Jagodin-mala and the excavations at Mediana (Kanitz 1991, 174). In 1870 Kanitz visited the regions around Svrljig and followed the road leading to Stara Planina and its most important peak Babin Zub, and passed through the village of Izvor (today's Jalovik Izvor) and Berilovac, for which he said it was "the crossroads on the road leading from Niš and Pirot across the Balkans to the Danube" (Kanitz 1991, 228). However, Kanitz did not record the ancient and medieval ruins from the territory of Svrljig and its environment. This would be done in the early twentieth century by the historian and archaeologist Nikola Vulić (1872-1945) (Ljubomirović 2013).

\section{NiKola Vulić - A FAmouse ARCHAEOLOGIST AND Historian}

Nikola Vulić was a teacher at the Belgrade Higher School, then at the Belgrade University and one of the greatest Classical scholars in Serbia. He is a researcher whose works established the methodological principles of critical studies in the history of ancient times, epigraphy and archeology. Vulić was equally successful as a teacher and as a scholar. His bibliography (550 scientific papers, reviews, and displays) shows that he was a prolific researcher (Maric 1958, 5-56). Most of the time he spent in his office where, in peace and quiet, he could devote himself to a book and follow the contemporary scientific literature in the field of ancient history. In the scientist's manuscript legacy, we find that Vulic had many friends all over the world with whom he maintained a regular correspondence, and 
who sent him the latest scientific publications. ${ }^{1}$ About his commitment to science and office work the scholar himself noted:

"I was born, I think, for a monk. Anyway, loneliness is for me. Most of all I love and have always loved, from the early days, to be completely alone, surrounded with books. Company distracts me, talks make me tired. My idol has always been a book so that I can read all day and work ... Unfortunately, during the last years reading makes me tired and I cannot work more intensely than five or six hours a day. I am often angry because of this, because there are so many beautiful books that I would like to study and so many scientific problems that interest me."2

Still, archaeological research was the most interesting to Vulić, and therefore he did not use his summer holidays to rest but to organize archaeological excavations at sites throughout the Kingdom of SCS. In his autobiography Vulić gladly remembered them:

\begin{abstract}
"My archaeological excursions throughout the land, throughout Serbia and Macedonia, Sandžak and by the Danube, have lasted for forty years by now. It was very hard work. Often there was hunger, or cold, more often suffering from the heat; I would be crossing a deep river with danger or walking precipitous mountains, overturning hundred-pound heavy monuments, sleeping on the solid ground, many a time putting my life at risk. This I do not regret. Successes were divine. My excavations particularly gave excellent results: in Trebenište I found archaic tombs filled with gold and precious art objects; near Skopje I dug a huge and opulent Roman theater, by the Danube, I began to examine the Roman limes." ${ }^{3}$
\end{abstract}

\title{
2.1 Vulić's archaeological map
}

Vulić first visited Southeast Serbia, Niš and the surrounding area, together with Anton von Premerstein in 1899 when the two of them explored the Fortress, and then stayed in Ravna near Knjaževac, where they found a number of monuments later published in the Monument of SRA (Vulić and Premerstein 1900, 18-37). From 1903 Vulić continued to organize the archaeological research himself on this territory. He visited Niš in 1905 and on that occasion made copies of the inscriptions he discovered, but also visited the sites around the city. In the surrounding village of Balajnce he visited the ruins which he claimed to be the remains of a city but did not state which one, thus the later researchers of this site took Vulić's results as their starting point (Jovanović 2003, 23-37; Milinković 2005, 163-182). However, A. Jovanovic's presumption that in the ancient period there was an important military fortification near Balajnac has not yet been proven, and the latest archaeological excavations were unable to confirm this hypothesis (Jovanović 2003, 36-37).

Vulić inserted data collected from the sites he was visiting into his unpublished notes titled "Appendices to the archaeological map section of Niš", which are part of his written legacy. ${ }^{4}$ The manuscript contains a list of all the places around Niš that Vulić visited and where he found sites from the Roman period. The sites are divided into five major units depending on the area where they are situated. The first group consists of villages around Svrljig. Vulić stated that in the municipality of Niševac, at a place called

\footnotetext{
${ }^{1}$ NLS, R 432/7, 47.

${ }^{2}$ NLS, R 342/2a, 5 .

${ }^{3}$ NLS, R $432 / 2,8$

${ }^{4} \mathrm{NLS}, \mathrm{R} 467 / 7 \mathrm{~b}, \mathrm{I}-\mathrm{V}$.
} 
"Banjica" foundations of Roman buildings were found originating from the second to the fifth century. On the same site, $200 \mathrm{~m}$ above the mill, foundations of an early Christian church from the fourth century were excavated together with a vaulted tomb. ${ }^{5}$ Archaeological excavations proved that the villagers had dug up a lead coffin in the church, and parts of the marble record stone like a framework for the label was also found, but the label space had been broken and missing (Oršić-Slavetić 1936, 170-174). Also, the foundations of Roman buildings were discovered at the site known as "Crkvište" by the mill of Vladimir Jovanović. ${ }^{6}$ The remains of a Roman gravel road were found on the stretch from Svrljig to Plužina, on the property of Tihomir Radivojević, Jakim Vujić and Petko Mladenović. Kanitz found in Plužina a milepost Trebonijana Gala which Vulić then published in the Monument of SRA (Vulić 1941-48, No 417). The marble female statue mentioned by Kanitz was also from Varoš, yet there were no records on it in Vulić's notes (Kanitz 1991, 143). In Gulijan, 200 m east of the village, the foundations of the Roman city were seen, while the remains of Roman bricks were found in Periš, Manojlica, Popšica and Ribar. As Vulić wrote "the villagers in Manojlica showed him coins of Constantius and Julius allegedly found at the site." 7 Vulic noticed foundations of the Roman tower on the hill in the village of Crnoljevica, at the place known as "Perivoj".

The second group comprises those sites that are in immediate surroundings of Niš: Kravlje, Hum Komren, Kamenica, Donji and Gornji Matejevac, Donja and Gornja Vrežina, Knez selo and Malča. ${ }^{8}$ Among the significant discoveries from these territories Vulić recorded the remains of military facilities as well as a brick tomb towards Hum at a place called "Ribnik". On the slope of Vinik the remains of a villa from the second and third century were discovered and as Vulić wrote "under the remains of a wooden building there a large chamber with denars was found." The money was minted from cleaner silver alloy and was found in a large earthenware pithos and is kept in the National Museum in Belgrade and the National Museum in Niš (Petrović 1999, 62-63). In 1910 a vaulted tomb was dug up in Malča at a place known as "Ulica", $1 \mathrm{~km}$ north of the village but sufficient data about it is lacking.

The third group consists of sites in Prosek, Gornje Medjurovo, Malošište, Perutina, Klisura, Kočane, Gabrovac and Vukmanovo. ${ }^{10}$ Vulić noted that the foundation and walls of the great Roman city were discovered in Klisura, on the property of Dragutin Stojiljković. The foundations of the house with a hypocaust and mosaic were in front of the property gates. In Gabrovac, on the hill "Kamara" on the estate of Dušan Cekić, early Christian church foundations were excavated and a label with the monogram of Christ was preserved, which Vulić published in the Monument of SRA (Vulić 1934, 48-49; OršićSlavetic 1934, 173). In Vukmanovo, near the school, he saw the remains of Roman tombs and coins from the fourth century.

The fourth group of sites includes Brzi Brod, Suvodol, Berbatovo, Donji Barbeš, Grkinje, Gadžin Han, Draškova Kutina, Kopirivnica, Jagliče, Čagrovac, Čelije, Miljkovac,

\footnotetext{
${ }^{5}$ NLS, R 467/7b,

${ }^{6}$ NLS, R 467/7b, I

${ }^{7}$ NLS, R 467/7b, I

${ }^{8}$ NLS, R $467 / 7 b$, II

${ }^{9} \mathrm{NLS}, \mathrm{R} 467 / 7 \mathrm{~b}$, II

${ }^{10} \mathrm{NLS}, \mathrm{R} \quad 467 / 7 \mathrm{~b}$, III
} 
Krastavče, Ovsinjinac, Šebet and Veliki Vrtop. ${ }^{11}$ Niška Banja, Jelašnica, Ostrovica, Toponica, Oreovac and Bela Palanka belong to the fifth group of sites. ${ }^{12}$ Among the significant findings Vulić mentioned the remains of a Roman villa near Brzi Brod. The villa dates from the fourth century and the remains of mosaics, hypocausts, bathrooms were found and Vulić, in describing the villa, referred to F. Kanitz "who was digging at the site and described mosaics." ${ }^{\prime 3}$ During the summer months in 1935 and 1936 Vulić lived in Niš, supervising the archaeological works in Brzi Brod and in Niška Banja. A chamber with a perfectly created mosaic was discovered during the excavation in Brzi Brod. Eminent archaeologists, including Vulić, recommended that the mosaic be conserved and a structure of solid materials be raised above it. Vulić presented the proposal that the chamber with a mosaic was a part of the palace of the Emperor Constantine, therefore, excavations should be continued fast as soon as the structure was lifted above the mosaic. ${ }^{14}$ A protective building was built in 1936 and excavations continued confirming Vulić's assumption that it was a remarkable building (Oršić-Slavetić 1934, 301-310). A monument was discovered in Ovsinjinac presenting a Thracian horseman which Vulić published then in Monument LXXV (Vulić 1933, 54-55). Vulić processed epigraphic monuments in Niš as well, and was the first scientist who pointed out "a label that talked about a character who is trained in the naval service." ${ }^{.15}$ Based on this inscription, Vulić concluded that there used to be a small floating fleet on the Nišava river, which was confirmed by other scientists many years later (Petrović 1999, 52). During these site visits Vulić compiled a collection of incuses and photographs of Greek and Roman inscriptions and reliefs. ${ }^{16}$ He participated in the creation of collections Corpus Inscriptionum Latinarum and Corpus Vasorum, Archaeological maps and Dictionary of Medieval Latin (Vulić 1936, 412-413). Vulić worked most intensely on a corpus of Latin epigraphic monuments, where all of the new labels which were not included in the Berlin Corpus Inscriptionum Latinarum should be included and where the old labels' edition from the territories of Moesia, Thrace and Macedonia should also be included. Vulić's dedicated work in the field of archeology and epigraphy is of great importance and is a contribution to both national and world science. Significant results could only be achieved through systematic research that required considerable financial resources. If one takes into account the time Vulić lived and worked in, the war and period between wars, it was not possible to count on greater investments in this scientific discipline. However, with the available funds, often himself financing the trips, Vulic managed to explore some of the most important sites in the country.

\section{CONCLUSION}

The Svrljig territory and its environment attracted the attention of researchers starting from the nineteenth century and Kanitz's visits of this terrain. The historian and archaeologist Nikola Vulić visited and compiled a detailed list of all visible objects and

\footnotetext{
${ }^{11}$ NLS, R 467/7b, IV

${ }^{12}$ NLS, R 467/7b, V

${ }^{13}$ NLS, R $467 / 7$ b, IV

${ }^{14}$ ANM, Report of the Moravian Banate Museum Banu, 8.09.1935.

${ }^{15}$ ANM, Niš Museum to Banska Government on the Transfer of the Monument, 27.03.1935.

${ }^{16}$ Yearbook of SRA XXII (1909), 194.
} 
findings at the sites in Svrljig villages in the first half of the twentieth century. In 1997 the archaeologist and director of the Institute of Archaeology, Petar Petrović began preparations for significant research in the area of Svrljig, precisely locations in Niševac and Svrljig-city. ${ }^{17}$ He considered the possibility that the station Timacum Maius could have been located in the area of today's Svrljig. ${ }^{18}$ The untimely death of this outstanding scientist prevented him from proceeding with future studies. Archaeological works on the territory of Svrljig begun by the Institute for Balkan Studies SASA and Cultural Center in Svrljig in 2008 led to significant discoveries, justifying the hitherto research, but also initiated the need for organizing new systematic archaeological excavations.

\section{REFERENCES}

Jovanović, A. Archaeological Records from Late Antique Nais and the Environment, Niš and Byzantium I (2003): 23-37.

Kanitz, F. Land and Population-from the Roman period up to the end of nineteenth century II, Beograd 1991.

Kanitz, F. Die römischen Funde in Serbien. Sitzungsberichte der Philosophisch-Historischen Classe der kaiserlichen Akademie der Wissenschaften in Wien, 36. Wien (1861): 195-203.

Ljubomirović, I. Nikola Vulić- a Classical Historian, Niš 2013.

Marić, R. Bibliography of Dr Nikola Vulić, Starinar IX-X (1958-1959): XV-XXIV: In memoriam to Nikola Vulić

Milinković, M. Some Observations on the Early Byzantine Fortifications in Southern Serbia, Niš and Byzantium III (2005): 163-182.

Oršić Slavetić, A. Archaeological Survey of Niš and the Surrounding Area, Startinar VIII-IX (1933-34): 301-310.

Oršić Slavetić, A. Notes from a Journey, Starinar X-XI (1935-36): 170-174.

Petrović, P. Antique Svrljig in: Cultural History of Svrljig, Vol. II: Language, Culture and Civilization (ed. S. Petrović), Niš and Svrljig: Education and National University, (1992): 121-132.

Petrović, P. Mediana, the Residence of Roman Emperors, Niš 1994

Petrović, P. Niš in Ancient Times Niš 1999.

Petrović, V. Filipović V. and Milivojević, S. Svrljig Area in Prehistory, Classical Period and the Middle Ages, Belgrade 2012.

Timotijević, M. Visual Representation of Serbia in the Works of Felix Kanitz in: Pictures from the Balkans by Felix Kanitz (edited by Dj. Kostić), Belgrade (2011): 93-115

Vulić, N. and A. von Premerstein, Ancient Monuments in Serbia, Spomenik XXXVIII (1900): 18-37.

Vulić, N. Ancient Monuments in Serbia, Spomenik XXXIX (1903): 43-89.

Vulić, N. Facilities, International Academy Union, JIC II (1936): 412-413.

\section{UNPUBLISHED SOURCES}

The Legacy of Nikola Vulic, National Library of Serbia

NBS, R 342/2a, 5.

NBS, R 432/7, 47

NBS, R 432/2, 8.

NBS, R 467/7b, I-V.

The Archive of National Museum of Nis

ANM, Niš Museum to Banska Government on the Transfer of the Monument, 27.03.1935.

ANM, Report of the Moravian Banate Museum Banu, 8.09.1935.

\footnotetext{
${ }^{17}$ V. Petrović, V. Filipović and S. Milivojević, Svrljig Area in Prehistory, Classical Period and the Middle Ages, Belgrade 2012

${ }^{18}$ P. Petrović , Antique Svrljig in: Cultural History of Svrljig, Vol. II: Language, Culture and Civilization (ed. S. Petrović), Niš and Svrljig: Education and National University, 1992, 121-132.
} 


\section{DOPRINOSI ISTORIJI ARHEOLOŠKIH ISTRAŽIVANJA U SVRLJISKKOM KRAJU}

Prvi istraživač Niša i njegove okoline krajem XIX veka bio je čuveni putopisac Feliks Kanic (1824-1904). On je započeo rad na arheološkoj mapi Srbije 1861. godine. O antičkim ostacima sa teritorije Srbije Kanic je uvidu tehničkih crteža ostavio vrlo precizne i jasne ilustracije. Materijal su činili: mape, planovi, prepisi tekstova i predstave pojedinih predmeta i spomenika u celini ili u pojedinim detaljima. Kanicovi radovi su najviše vrednosti imali sa arheološkog gledišta i njegov dorpinos proučavanju rimskog nasleđa u Srbiji, samim tim i u Nišu i njegovoj okolini je veoma značajan. Njegov posao su početkom XX veka nastavili Nikola Vulić i Antun fon Premerštajn. Vulić je predano radio na obilasku terena $i$ prikupljanju rimskih starina. Osim lokaliteta na teritoriji grada Niša on je obišao i Svrljig i njegovu okolinu. Podatke o arheološkim nalazima sa ovih lokaliteta nalazimo u Vulićevim neobjavljenim beleškama naslovljenim "Prilozi za arheološku kartu sekcija Niš", koje su deo Vulićeve rukopisne zaostavštine koja se čuva u Narodnoj biblioteci Srbije.

Ključne reči: Feliks Kanic, arheološka karta, Svrljig. 